\title{
Engaging Deweyan Ethics in Health Care: Leonard Fleck's Rational Democratic DELIBERATION
}

\author{
Danielle L. Lake
}

\section{ABSTRACT}

While the U.S. health care system is failing to serve many of its citizens, agreeing on what is wrong as well as on how to fix the system seems impossibly optimistic. Leonard Fleck attempts to do just this-to diagnose the problems and to address these problems through dialogue. Dewey's philosophy supports the direction of Fleck's work, but it also highlights serious problems with this argument. And when far less rich countries are able to provide better care to all their citizens for far less, we have a system in need of a deliberative process that works.

The greatest change, once it is accomplished, is simply the outcome of a vast series of adaptations and responsive accommodations, each to its own particular situation."

It is in no way controversial to say that the U.S. health care system is failing to serve many of its citizens satisfactorily. While it is certainly true that most U.S. citizens are dissatisfied with our current health care system, creating agreement through open dialogue on what, more precisely, is wrong with the system, as well as on what we should do to fix the system, seems to many to be impossibly optimistic. Leonard Fleck, professor of philosophy and medical ethics at Michigan State University and author of Just Caring: The Ethical Challenges in Health Care Rationing and Democratic Deliberation, attempts to do just this-to diagnose the root problems we must confront in our health care system and address these problems through open dialogue between citizens-by relying on a process he calls rational democratic deliberation. In fact, the majority of Fleck's professional work is focused on rational democratic deliberation as it relates to and impacts health care policy. Fleck began his academic career studying John Dewey's work and served as a member of the Hillary Rodham Clinton Task Force on Health Reform (1993). While a seminal and powerful experience informing his subsequent work, this task force was ultimately a doomed endeavor, since public talk about rationing health care resources has been likened to political suicide. ${ }^{2}$ These same concerns, however, have been 
reiterated in President Obama's Affordable Care Act and the extreme rhetoric surrounding its Supreme Court review in the spring of 2012.

Attuned to the political rhetoric of today, Just Caring's more specific focus is first on raising awareness about the need for publicly and justly rationing our health care resources and then, secondly, on generating dialogue that leads to communal decisions about how we should ration our health care resources justly. ${ }^{3}$ Vaguely along these lines and in the process of generating a proposal for health care reform, the Senate's 2009 health care reform bill was built by conducting bipartisan committee meetings "in the open," going so far as to hold these meetings in the public, broadcasting them on C-SPAN, and posting them on the web. More significantly, committee members made an effort to engage in town hall meetings in their various districts in order to gather input and receive feedback from the American public. Using Shane Ralston's distinction between consulting and deliberating, these efforts fall more closely in line with public consultations than with serious deliberative endeavors. They can be seen, though, as a small step in the right direction. According to Walter Feinberg, they represent a too narrow image of a modern public, given new and more informal vehicles for public participation. ${ }^{4}$ Such public deliberations must be, according to Fleck, a dialogical processes used to address collective problems that cannot be solved without cooperation. While Fleck only briefly references John Dewey specifically in the beginning of his project, he relies heavily on a pragmatic philosophical background to construct and argue for the usefulness of rational democratic deliberation. ${ }^{5}$

Though Dewey's work does not discuss health care issues in any detail, his philosophy continues to give us guidance in these matters. As James Campbell says, "the ongoing importance of Dewey's contributions is to be found . . . in his adumbration of a social method for developing, publicizing, and evaluating suggested modes of action. His goal here is the creation of a vibrant democratic society that addresses its ills through cooperative inquiry." Dewey's method and his focus on the importance of dialogue with diverse others, on education and on the conservative nature of our habits and our institutions more broadly, gives us insight into why our broken health care system manages to continue on. When over forty-seven million Americans are currently without health insurance, when the number one cause of bankruptcy in this country is unpaid medical bills, and when far less rich countries are able to provide better care to all their citizens for far less, we certainly have a system that is not working. Dewey's philosophical writings do not and could not speak directly to these current concerns, since our medical science and institutions have changed so drastically; however, Dewey's method was designed to respond to sensitive and complex communal issues which could not be resolved by relying on experts or political leaders alone. Indeed, his ethics, according to Gregory Pappas, begin always in our lived experience. ${ }^{7}$ A more extensive examination of Dewey's writings will be shown in general to support the direction 
in which Fleck suggests we move. However, Dewey's philosophy also highlights problematic concerns with Fleck's argument that must be addressed before we can seriously endorse his project as feasible.

\section{What is Rational Democratic Deliberation?}

In order to address Fleck's suggested solution fully, the intention of rational democratic deliberation must first be highlighted. We must keep in mind, Fleck says, that "in the deliberative process we are not seeking truth; we are seeking to construct a resolution to a public problem." ${ }^{8}$ We are seeking solutions that work, solutions that meliorate the very serious health care problems we are facing. Amy Gutmann and Dennis Thompson reiterate the value of deliberation within the political realm. What we really need is not theoretical ideals or "hypothetical agreement." Instead, we need to "encourage citizens to face up to their actual problems by listening to one another's moral claims." "We face numerous, very serious health care problems that often cannot justly be solved individually; pragmatists suggest that we need to address these problems through a communal discourse that seeks workable solutions through "practical agreement." In fact, Dewey warns us that "those who wish a monopoly of social power find desirable the separation of habit and thought, action and soul.... For the dualism enables them to do the thinking and planning, while others remain the docile, even if awkward instruments of execution."10

This is especially problematic in a partially for-profit health care system where those in power have a vested interest in a status quo that is not working for most Americans. Pharmaceutical companies, rehabilitation centers, insurance companies and other facilities are, for instance, most often owned by the private sector in the United States. Most citizens, especially those under 65, receive health insurance through a private company chosen by their employer, not through the government. Most often, the ultimate goal of these institutions is to make money. These providers would be leery of a system overhaul to the extent that the current system is profitable, even if such a system is also inefficient and unjust. A focus on workable solutions is especially critical in bioethics, where our beliefs, practices, and institutions have life and death consequences. Fleck directly addresses these concerns by first seeking to raise awareness about the current quiet and unjust form of rationing occurring in the United States and then defending the need for a consistent and more just form of health care rationing. ${ }^{11}$

In practice, this means that we need to look at the specific cases that make up the larger problems; we need to discuss possible solutions and weigh their consequences; we need to make decisions and yet still be amenable to revising those solutions. For instance, given that we face limited resources, where do we decide to draw the line in allocating these resources? We currently and quietly ration-at least in part-by leaving many of the uninsured without care or by forcing them to pay higher out-of-pocket costs for their care than their insured counterparts. 
Instead, we need to start asking and discussing publically some tough questions. When care is marginally beneficial and very costly, do we continue to support it given that we may have to deny others more beneficial and less costly care?

Democratic deliberation has the potential to address complex and controversial social problems more justly and fairly by involving those affected by these problems in the decision-making process. When dealing with problems that are especially complex, problems that experts alone cannot solve for us (i.e., problems most often found in the public policy domain), it seems most fitting to ensure that those affected by the problem have an opportunity to participate in the process. Such problems are not amenable to clear, quick and final resolutions. Theorists of democratic deliberation tend to echo Dewey in arguing that "the principles and values with which we live are provisional, formed and continually revised in the process of making and responding to moral claims in public life."12 In the end, Fleck argues, we, as a community, will come to a more legitimate decision if we first learn about the issue in its complexity and exchange reasons about how we should respond to it.

\section{Deliberative ReQuirements}

In order to confront these questions we need at the outset to develop a deliberative committee whose work meets a number of the criteria Fleck puts forward. First, the deliberative process must be open to the public and transparent. Second, participants in the process must not feel coerced and must understand themselves to be equal to their fellow deliberators. Third, participants should in some sense be impartial, at least in so far as they are ignorant of their own future health care needs. ${ }^{13}$ Fourth, participants should present only public reasons to one another. Fifth, participants need to realize that any decisions they make can possibly impact their "future possible selves." ${ }^{14}$

The third and fifth measures could be cause for concern. This is because deliberation, for Dewey, is not about calculating indeterminate future results. "No shrewdness, no store of information will make it [the future] ours." ${ }^{\prime 15}$ Fleck's deliberative model works with Dewey's concern here on a social level since the committee must always be willing to reexamine any policy decisions in light of their future consequences. That is, any implemented policy is subject to scrutiny and revision. On an individual scale, however, we may find ourselves endorsing future rationing decisions about which we later realize we were entirely mistaken. In order to promote consistency and fairness we are to some extent simply stuck with our mistake. ${ }^{16}$ In reality, according to Fleck, there are no decision procedures which yield perfectly just outcomes every time they are applied. ${ }^{17}$ Along this vein, Aaron Schutz-writing on Dewey's work to foster effective action within our communities-reminds us that "abstract plans become concrete only when they are appropriated in the context of actual use." For this reason "it seems clear that any plans for achieving any aim will always be somewhat sketchy."18 
Fleck further argues that in order to deliberate successfully we need a sufficient level of open-mindedness, mutual respect, honesty, transparency and the willingness to listen to all variety of relevant positions. Our political landscape is not currently filled with such things, however. We are very much divided into factions and these factions, as Dewey notes, seriously undermine the kind of participatory democracy we seek: "Too often the man who should be criticizing institutions expends his energy in criticizing those who would re-form them." Such individuals are really, according to Dewey, rejecting any possible disruption to their own vested interests. ${ }^{19}$ We need to recognize that "amicable cooperation" is essential to democracy and that such cooperation can get us beyond divisive differences. ${ }^{20}$ Truly democratic communities foster an awareness of our interdependence and our shared interests. It is through such "experimental and personal participation in the conduct of common affairs" that we come to see our "social responsibilities."21

To this extent, a public, as defined by Schutz and Dewey, consists of groups of people who are affected by others, including those far-removed from us. ${ }^{22}$ Since, today, our lives are heavily affected by the actions of unseen others, a first step forward takes place by perceiving this interconnectedness. "With perception," Schutz says, "comes the possibility that the source of these consequences might be grappled with and regulated." ${ }^{23}$ In fact, "'we' and 'our,' exist only when the consequences of combined action are perceived and become an object of desire and effort." ${ }^{24}$ Fleck and Dewey find further common ground in arguing that citizens do not need to become experts per se, but instead need a willingness to deliberate. "What is required," Dewey writes, "is that they have the ability to judge of the bearing of the knowledge supplied by others upon common concerns." 25

On the other hand, Reinhold Neibuhr, a strong critic of Dewey, suggests that while "the development of rational and moral resources may indeed qualify the social and ethical outlook ... it cannot destroy the selfishness of classes." ${ }^{26}$ Perhaps we cannot, in the end, get past our own biases and loyalties. ${ }^{27}$ Neibuhr does allow, though, that we can make some small progress through such methods. In Deweyan terms, we would be developing the habits required of such endeavors through engaging in and reflecting on the process. The extent to which we can get beyond divisive factions and effectively cooperate cannot be pinpointed until we have given Fleck's suggestions an extended try. Developing such a deliberative body also works to shape our expectations and direct our impulses into new habits which make the likelihood of successful future deliberative efforts even more likely. ${ }^{28}$ We must first, though, find and move others to engage.

Inspiring a willingness to listen is done through causing puzzlement. While Fleck chooses the word puzzlement, what he is pointing out is that we need to make others aware of a situation that is really, in Deweyan terms, indeterminate. ${ }^{29}$ It is the indeterminate situation that provokes uncertainty. Effectively engaging an individual who has already made a determination about the matter under 
examination requires us to bring to her awareness components of the situation she has yet to consider. It is the predetermined state of mind that is "the chief obstacle to the kind of thinking which is the indispensable prerequisite of steady, secure and intelligent social reforms." ${ }^{30}$ Some bioethical concerns seem so complicated and subject to various interpretations that causing puzzlement may not be too difficult. Fleck is an expert at this in his various works. ${ }^{31} \mathrm{He}$ is able to generate seemingly countless, complex problematic situations that do not offer easy or simple solutions to the careful listener.

Fleck's plan to incite puzzlement depends on making others aware that the situation is in fact inherently doubtful. Oversimplifying the reality of our health care problems or finding ourselves ignorant of the concerns of others allows individuals to avoid such complex and puzzling problems. For instance, a reverence for life does not get one out of the difficult problems we must confront. Neibuhr writes that "believing that reverence for life is basic to all morality," an individual "may have to make a choice between types of life, and sacrifice an unborn infant to save the life of a mother." A reverence for life does not get one out of the problem of rationing limited resources and thus of making tough choices about who gets care and who does not. "A reflective morality is constantly under the necessity of reanalyzing moral values which are regarded as intrinsically good, of judging them in instrumental terms." ${ }^{32}$ Dialogue exposes these problems and a focus on real, complex problems helps to create the potential for working solutions.

By openly discussing the problems involved in health care rationing, we can more clearly see how we are all involved in this problem together. A truly democratic society is reliant upon its ability to take note of how our actions affect one another. ${ }^{33}$ Schutz recognizes this concern: "A crucial criteria that distinguishes more from less democratic societies," he says, "is the sensitivity of citizens to, and ability to act to overcome, obstacles that arise in their environment." ${ }^{34}$ While most people feel an obligation towards their immediate environment, many do not feel so obligated to the greater society. Perspectives, here, need to be broadened.

\section{The Limits of Our Deliberative Model}

Fleck at times relies on John Rawls in his work, and this has the potential to become a problematic deviation from Dewey. This first arises when considering Dewey's emphasis on context. For instance, Fleck concludes that the deliberative process can lead to the "fundamental moral virtue of impartiality" that Rawls' develops through his disembodied spirits. ${ }^{35}$ Endorsing such a removed position of impartiality is highly problematic. According to Dewey, there is no position from nowhere; there is no stripping ourselves of all personal identifying features. The attempt to do so, even theoretically, is dangerous, as it often leads us to have more faith in our current conclusions and less in other possibilities than the situation may warrant. Eric Weber, writing on Rawls and Dewey, comments on this same problem,

\section{E\&C Education and Culture}


noting that one of Rawls's mistakes comes from his reliance on the fully rational adult, a person who is somehow "untarnished by the hands of cultural influence." ${ }^{36}$ Rawls's theory, in the end, relies upon an "untestable and unempirical" foundation, whereas Dewey begins by situating himself within experience. By endorsing our deliberative efforts as completely impartial, we are forgetting to remain diligent about the potential for fallibility, forgetting to attend to our own context, and thus moving away from the possibility of reexamining together the position at hand. Dewey is very concerned with how time and distance "affect both consequences and the ability to foresee them and to act upon them. ${ }^{{ }^{37}}$ Pappas reinforces the importance of context in Dewey's ethics. We must, he says, remember to "attend to the particular, the qualitative, and the unique equipped with the best habits of reflection, imagination, and sensitivity available." ${ }^{38}$ Fleck, too, casually endorses our ability to use reason to predict how we would feel in some distant future, facing some unknown illness.

One of the most potentially troubling conclusions Fleck comes to is that we can support or reject some health care policies outside of any need for deliberation. We are able to do so, he says, because some potential decisions would clearly violate "constitutional principles" of health care justice. These constitutional principles-equality, liberty, fair equality of opportunity, ${ }^{39}$ publicity, respect for persons, liberal neutrality, ${ }^{40}$ and reciprocity-are derived in part from Norman Daniels, in part from Rawls, and in part from Fleck's own work in this area. The claim is not that this is a complete list of principles, but that "these principles seem necessary to sustain the effort to articulate a fully adequate pluralistic conception of health care justice." ${ }^{\text {"1 }}$ Such principles appear problematic because, for Dewey, "every measure of policy put into operation is, logically, and should be actually, of the nature of an experiment. ${ }^{\prime 42}$ Now, broadly construed, Fleck's point that these general principles can and do offer us guidance could be endorsed by Dewey. There is nothing inherently problematic with loose rules or general guidelines as long as they are not thought to be absolute. In fact, general guidelines are essential to day-to-day decision making. Such rules, though, should be subject to intense scrutiny and testing, and Fleck argues they have been.

Pragmatists, however, strongly endorse morality as something we do together; as a social practice we engage in, it cannot be understood from above or outside of our community. Dewey, in fact, says that "we cannot set up, out of our heads, something we regard as an ideal society." Instead, we should attempt to "extract the desirable traits of forms of community life which actually exist, and employ them to criticize undesirable features and suggest improvement." ${ }^{\text {"33 }}$ Conflict and confusion are a necessary part of the educational process, of social cooperation. Weber tells us that "they are," for Dewey, "challenges to which we must rise" and "the reasons we must continue to grow." ${ }^{\prime 4}$ In contrast, Rawls's theory is "backwards" in that it begins at "an ideal society and works inwards." ${ }^{\text {"5 }}$ Thus, we see that such constitutional 
principles, applied prior to community involvement, violate Dewey's maxim. In The Public and its Problems, Dewey again warns us away from the notion that we define a "model pattern" of what is good and true: "It, more than anything else, is responsible for the effort to form constitutions offhand and impose them readymade on peoples. ${ }^{346}$ Campbell, writing about Dewey, says that such constitutional principles leading to social actions need to "go through a process of cooperative examination and social evaluation before their enactment." ${ }^{37}$

Hence, Fleck's belief that the principles can yield at least some answers prior to and without the need for deliberation is problematic. He suggests that it is only when such principles fail that we require RDD. Our principles fail us at times because "some moral problems are too complex, involve too much factual uncertainty, [and] are open to reasonable (but conflicting) conceptual characterizations." ${ }^{\text {"48 }} \mathrm{To}$ the extent that Fleck recognizes the severe limitations of abstract theory in practice, then, he is being naturalistic. On the other hand, the constitutional principles are appealed to as foundational, as so reliable that any potential decision violating them would not even be taken under consideration by a deliberative body. At this point, such principles start to take on a reverence which removes them from the necessity of continuous inquiry, inquiry that should be "connected as well as persistent" so as to "provide the material of enduring opinion about public matters." ${ }^{\text {"9 }}$

Fleck's principles define the appropriate space for deliberation so that, for instance, an individual trying to argue that AIDS patients should receive no health care cannot hijack the deliberative committee's time and resources. Rejecting such a proposal "out of hand is the only reasonable and liberally appropriate response." Appealing to one or more of the above constitutional principles when a violation is blatant gives us the means to justify our refusal to waste time and resources on considering such a measure. We are, in some sense, granting authority to the principles and the deliberative committee so that we can more adequately restrain the dynamics of political power. For example, when examining President Obama's attempts to engage various local communities in town-hall meetings in relation to our health care crises we see that many of these meetings were in fact hijacked by those wishing only to disrupt any attempt at genuine dialogue. Setting forth criteria to shape the dialogue is going to be key to our chances of gaining ground on these matters. Granting authority to such principles can, to some extent, be interpreted as an act of trust. Such trust, though, relies upon our experience of the committee and the principles as reliable and competent. While Fleck views the principles in such a way based on his own experience with them, the general public obviously lacks such experience. There may be a need tentatively and temporarily to place trust and, based on future experience, renew or revoke such trust as we see fit.

Another potential problem these principles yield comes from the implication that they are in some sense absolutely right and universally applicable. As we have seen, principles must be contextualized; they are contingent and situational. ${ }^{51}$ 
In one sense, Fleck sees this need for localized principles, since his deliberative model is meant to apply to the community thinking the issue through, although the community in this model has the potential to be represented by a state or the entire nation. In fact, defining the space of such a public is not simply problematic for Fleck, but also so for Dewey. As Schutz's "Parodox of Size" points out, Dewey's community work extended almost exclusively to the local community, even though Dewey intended his method to be more broadly applicable. He never directly tells us how we accomplish such a goal on a wider scale. ${ }^{52}$ Empowering citizens to engage others within their community without exploring how such deliberative practices can be practically engaged on a wider scale is a serious problem for Dewey, Fleck and democratic deliberation more broadly. ${ }^{53}$

In the end, Fleck recognizes much of the tension between our theoretical principles and our very real, complex problems. He goes on to strike out at those who want to stick to universal principles. Individuals unwilling to engage at a communal level, criticizing experimentation and compromise, are, he says, simply attempting to keep "a clean conscious by failing to engage in the difficult ... moral compromises required by the problems of our complex social life and a complex health care system." ${ }^{54}$ Dewey echoes this concern by noting that, while we have become accustomed to the "experimental method in physical and technical matters," we are yet "afraid of it in human concerns. [This] fear is the more efficacious because like all deep-lying fears it is covered up and disguised by all kinds of rationalizations." ${ }^{\prime 55}$ In the end, these principles are only partially helpful. This is because Fleck recognizes the two main naturalizing criticisms of such constitutional principles: principles are often too abstract to be easily applicable in particular cases and they fail to offer guidance when there is a conflict between them. He emphasizes thatto some degree-we only have each other. Given this, we must grapple with these issues as a community in order to find caring, adequately just models for dealing with our limitless health care needs. The community at-large must have this opportunity partially because, in a pluralistic society, we cannot presume that those left out of the process will have come to a similar conclusion on their own, nor can we assume we have thoroughly covered all the bases without first openly listening to others. As Iris Marion Young points out, inclusion must be of deep concern if we are to "widen" and "deepen" our democracy.

In fact, for Young, "the normative legitimacy of a democratic decision depends on the degree to which those affected by it have been included in the decision-making processes and have had the opportunity to influence the outcomes. ${ }^{56}$ Formal inclusion is problematic in itself, but beyond these concerns is another set entirely. By inclusion, she is not simply talking about aggregating appropriate numbers of minorities and women, but is instead pointing to a deep, "internal" inclusion. Traditionally underrepresented people given some level of formal inclusion within democratic processes often find that the group does not consider their points of 
view worthy of consideration. ${ }^{57}$ Such documented concerns deserve closer attention and further treatment if Fleck's deliberative model is to get off the ground.

Fleck's work does attempt to resist some inherent biases by detaching itself from particular institutions, with their own interests to consider. He suggests instead that we develop a body of citizens that is sufficiently diverse and whose interests are not as a whole committed to any particular institution (i.e., a particular hospital or insurance company). ${ }^{58}$ There is more opportunity here for these individuals to be fair-minded and uncorrupted not only because they are officially unattached in this environment, but also because they are in dialogue with diverse groups of people. Such dialogue has the chance, Dewey says, to interrupt unreflective emotional and intellectual "habitudes" as well as to address any underlying fear of an experimental method to address human concerns; it thus has the chance to resist attempts on the part of "exploiters" to take advantage of unreflective "sentiment and opinion. ${ }^{39}$

Since RDD is ultimately an educative process, the likelihood of expanding and improving our judgments increases; our inherently limited perspectives are widened by the process itself, so the decisions arising out of this process are more likely to be collectively just. Dewey, in Human Nature and Conduct, points to this idea. He says, "education consists in an intelligent direction of native activities in the light of the possibilities and necessities of the social situation." ${ }^{60}$ Fleck's dialogue is designed to engage the surrounding community in these health care concerns so that policy decisions are directed towards meliorating the current situation. ${ }^{61}$ The solution Dewey posits involves direct interaction with others, just as Fleck's suggestion posits open dialogue. "The remedy," Dewey writes, "is not divorce of thought from intimacies of the direct contacts and intercourses of life, but a supplementation of limitations and a correction of biases through acquaintance with the experience of others" ${ }^{\prime \prime 2}$

\section{FifTeEn CRiteria for Evaluation}

Fleck works hard to provide us with the opportunity for such a remedy. He offers us a list of fifteen benchmarks by which we can judge the success of our deliberative efforts. In brief, the first three criteria are 1) the need to create puzzlement, 2) the need to use "available scientific knowledge honestly" while also recognizing that such knowledge is limited and fallible, and 3) the need to give reasons for the position we endorse. Criteria one and two clearly align with Dewey's own work. Fleck goes on to defend the third requirement by noting that the giving of reasons indicates we are "cooperating freely with one another to create and advance common goals-as opposed to having to be coerced by formal authority into participating." ${ }^{63}$ Therefore, the practice of reason giving looks to be an attempt to create an atmosphere where power is not coercive. The attempt to create an open space free from undue coercion is also reinforced by benchmarks six, seven, and eight. In 
a few words, Fleck tells us that 6) dialogue must be fair and impartial, 7) we must address our co-deliberators as equals, and 8) we must show respect for one another. Such conditions are definitely essential to our deliberative efforts, but putting such platitudes into practice and ensuring our efforts are not subject to unfair coercion is, as Young rightly warns, another matter entirely.

At this point there has been relatively little empirical analysis on the public's current attitude toward setting limits to health care nor towards using cost-effectiveness considerations in making decisions. ${ }^{64}$ Cost-effectiveness considerations, for example, ask us to consider how we want to use our finite resources (for we cannot invest everything we have in health care if we still intend to fund education and other goods). Until we as a society take a closer look at these situations, we cannot intelligently allocate our limited resources. Therefore, rational democratic deliberation actually has a lot of work ahead of it in educating U.S. citizens so they are more prepared to engage thoughtfully in this process of allocating resources justly.

Democratic deliberation is experiencing a resurgence in the United States. The work we have done so far suggests that much of "the public is both able and willing to engage questions about what types of services and what populations should be given priority for insurance coverage." This evidence also suggests that posing "high-stakes questions to a diverse group that is publicly accountable for the outcomes of their decisions motivates effective deliberative processes on the part of citizens." ${ }^{65}$ The Deliberative Democracy Handbook, for instance, provides a plethora of evidence that the public is "able and willing" to engage such issues

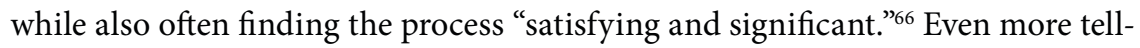
ing, the conclusions from such deliberations are often judged quite positively. By moving forward through trial-and-error, some of the specific questions above will find appropriate answers. The risk we take in beginning this process and failing seems negligible in comparison to continuing to put up with the injustices found in the current system. As Dewey would advise, failure here can always be a source for further instruction.

Another set of benchmarks-four, five, ten, and twelve-brings us back to the use of public reasons. In brief, the measures require us to 4) discern "value judgments that belong in the domain of public reason," 5) figure out which values matter for the issue under examination, and then 10) detect values we share in relation to the problem-at-hand, and, finally, 12) identify "public interests" we can use as reference points for judging potential policies. In asking us to identify shared values and reasons, we are encouraged to find some level of mutual understanding. Dewey also clearly recommends just such an expansion of perspective. Public reasons, since they avoid particular philosophic doctrines, are fallible and capable of undergoing revision based on new information. They are also context-bound. ${ }^{67}$ Through the use of public reasons, then, rational democratic deliberation "is about mutual education, mutual persuasion, and shared social problem-solving," not coercion or manipulation. ${ }^{68}$ 
Dewey refers to reason as "observation of an adaptation of acts to valuable results." Such reasons provide "a new motive for fidelities previously blind"; they set up "an attitude of criticism, of inquiry," and make "men sensitive to the brutalities and extravagancies of customs." ${ }^{\prime 69}$ This is precisely what Fleck is working to do. Dewey's description of reason here not only demonstrates an endorsement of the above measures, it also endorses Fleck's final four conditions. For instance, benchmark eleven asks us to identify the assumptions behind and consequences of the conclusions we are deriving through our deliberative efforts. ${ }^{70}$ Such a condition requires us to be "sensitive to the brutalities and extravagancies" of any potential policy we endorse. Benchmarks thirteen and fourteen ask us to produce some evidence that we have learned something of importance about the issue, and, secondly, that we have a better understanding of the complexity and "inherent uncertainty that must characterize such conversations." ${ }^{\prime 1}$ Lastly, benchmark fifteen asks us to consider whether we now have a greater tolerance for choices we may not make for ourselves. ${ }^{72}$ Such benchmarks align directly with Dewey's emphasis on the development of critical and inquiring minds.

Fleck informs his reader that his use of the word "rational" is meant to contrast with the kind of deliberation that is driven by power differentials, seeks only to maintain surface level appearances, and plays on the ignorance of the community ${ }^{73}$ Dewey says deliberation is rational to the degree that "forethought flexibly remakes old aims and habits, institutes perception and love of new ends and acts." ${ }^{74}$ Even Neibuhr's sense of rationality here aligns with Dewey and Fleck's focus on the rational:

The measure of our rationality determines the degree of vividness with which we appreciate the needs of other life, the extent to which we become conscious of the real character of our own motives and impulses, the ability to harmonize conflicting impulses in our own life and in society, and the capacity to choose adequate means for approved ends. ${ }^{75}$

We must recognize in our health, our own potential and future fragility, and in our own moments of need, the needs of others. This is essential if we are going to come together to find workable solutions not only for ourselves as individuals, but for our greater society. Dewey, along these same lines, advocates treating those who profoundly disagree with us as those from whom we should attempt to learn. This learning process has no terminus, but is instead on-going.

This learning process is continuous in part because decisions made through our deliberative efforts are subject to revision given changing circumstances. While the fact that this process is ongoing might seem disadvantageous (for this means the costs and time involved in the process are unending), given the rapid development of new technologies, the new results found in medical studies and the changing economic and social conditions we face, an ongoing process of dialogue and 
reevaluation is essential. We are not, however, starting from scratch every time we consider a new rationing scenario: "What will happen in practice is that our earlier collective deliberative judgments will be further refined and specified by what we learn in later deliberative efforts." ${ }^{\text {7 }}$

Through this process we are far more likely to develop consistent, just-enough rationing decisions. Fleck's work is thus grounded in Dewey's experimental method. By experimental, Dewey means that our decisions will be "subject to constant and well-equipped observation of the consequences they entail when acted upon, and subject to ready and flexible revision in the light of observed consequences." ${ }^{\prime 7}$ While this experimental method does not assure against future mistakes, "it would render failure a source of instruction." ${ }^{\text {"78 }}$ Our deliberative decisions must then be flexible if only because enacting them may bring about consequences we did not originally foresee, and unforeseen consequences often call for an adjustment in our original decisions. ${ }^{79}$ There is no need for criticism on this count since Fleck's deliberative model is designed in such a way that reevaluating previous decisions is a part of the committee's work. There are, however, a couple of further critiques we must consider.

\section{FURTHER CRITICISMS}

Another criticism comes from Reinhold Neibuhr and stems from a general concern about human nature. Neibuhr is concerned about the imaginative power of the human mind and its innate ability to extend itself. He says, "man will always be imaginative enough to enlarge his needs beyond minimum requirements and selfish enough to feel the pressure of his needs more than the need of others." ${ }^{\prime 8}$ And yet it is precisely this imaginative power of the mind which also allows us to imagine our future possible selves as suffering from any number of medical conditions. This imaginative power thus allows us to place ourselves in other's shoes and make more thoughtful, considerate and - to some extent - self-imposed rationing decisions. These decisions are self-imposed in that we are holding our future possible selves to the same standard as those who currently suffer from the particular medical condition under scrutiny. Neibuhr's critique about the over-extension of the self in one's imagination, then, can be taken up as a useful tool by which rational democratic deliberation becomes more feasible. On the other hand, Neibuhr's concern that we feel the pressure of our own needs far more intensely than we do the needs of others is, I think, a very real concern. Dewey, though, recognizes this concern as well: "The man who wears the shoe," he says, "knows best that it pinches and where it pinches" ${ }^{\prime 1}$ Present suffering often has the capacity to override just and rational choices we may have made in the past. The relative progress we can make on this front, though, cannot be determined without first making the effort.

A second, more problematic criticism of rational democratic deliberation comes out of the need for compromise. While Dewey would not find this to be 


\section{DANielle L. LAKE}

inherently problematic, it is far more difficult to accomplish than Fleck lets on. In fact, it is rare that deliberation actually ends in genuine consensus. ${ }^{82}$ The role of habit is not thoroughly addressed or redressed in Fleck's book; and while the role of habit is not central to Fleck's overall mission in Just Caring, taking it into consideration when judging the merits of rational democratic deliberation can be fruitful. First of all, however, we must get clear on what we mean by habit.

Dewey says, "all habits are demands for certain kinds of activity; and they constitute the self. In any intelligible sense of the word will, they are will. ${ }^{183}$ Habits are not only physical behaviors, but mental and moral attitudes as well. While all types of habits generally resist pressure from without, Dewey says that "habits of opinion are the toughest of all habits." Mental and moral habits have such power over us precisely because they are so much a part of who we are. Dewey goes on to say that we value the habits we do have if only because such habits literally limit our imagination. ${ }^{84}$ When such habits are "supposedly thrown out the door, they creep in again as stealthily and surely as does first nature. ${ }^{" 85}$ So while habits of opinion may prevent one from seeing the need to engage in dialogue or while they may shut such dialogue down, they may also creep back in after seemingly productive dialogue has taken place. The very "... nature of habit is to be assertive, insistent, and self-perpetuating." ${ }^{\prime 86}$ Dialogue may often fail to eradicate the habit itself. At the very least, we do not want to underestimate the power of habit.

On the other hand, habits are essential to our day-to-day functioning as well as to community bonding. We cannot, for instance, consciously and laboriously think through every action before we commit to it and still function in our day-today lives. Schutz reminds us that, for Dewey, "shared habits ... allow community participants to work together without constantly negotiating every action." ${ }^{87}$ They are the "glue that holds all communities together." ${ }^{\text {"It }}$ It in fact "only when we face an obstacle, when our habitual ways of doing things become problematic," that we need to be willing to consciously reexamine our thinking. ${ }^{89}$

Dewey warns us that "interference with a well-established habit is followed by uneasiness and antipathy." Beyond the uneasiness generated by puzzlement in someone who was before relatively sure of her stance, we also find that we generally have "an emotional tendency to get rid of bother." ${ }^{\text {"90 }}$ Yet there is still hope for dialogue here, and especially for rational democratic deliberation. Dewey finds this hope in "intermediate acts." We need to take "intermediate acts seriously enough to treat them as ends." ${ }^{" 1}$ Once we find ourselves puzzled we need to generate possible solutions, consider their consequences, make choices, pay close attention to the actual consequences of our decisions and modify our polices accordingly; we need to follow through. A more reflective process of engagement means that we become more careful about which habits we adopt and more flexible when they fail to lead us in the direction we want to go. ${ }^{92}$ According to Feinberg (2012), this means that we need to promote "habits of deliberation that accept the burden of judgment." ${ }^{\text {" }} 3$ Such actions are built into Fleck's rational democratic deliberation.${ }^{94}$ He suggests that 
we form committees which posit potential policy changes which are then enacted. These committees continue to meet and consider these problems over a period of years, giving them the potential to consider the situation after their policies have been implemented and to thus suggest further modifications. Having the ability and the desire to return to the problem and reconsider the implemented solution is highly important for Dewey: "The work of intelligence in observing consequences and in revising and readjusting habits, even the best of good habits, can never be foregone. ${ }^{95}$ Fleck leaves room here to do just this.

\section{CONCLUSION}

By focusing on the 'democratic' portion of Fleck's rational democratic deliberation, we can see the requirement for reflective action. Democracy, as Dewey conceived of it, is ". . . a means of stimulating original thought, and of evoking actions deliberately adjusted in advance to cope with new forces." ${ }^{\text {"96 }}$ While democracy in his time did not get to this point and-I would argue--still has not, Fleck's deliberation aims to do this, to intelligently adjust our actions to better cope with the situations we face. This process is designed to replace unreflective moral habits with habits that are "more intelligent, more sensitive, percipient, more informed with foresight, more aware of what they are about, more direct and sincere, more flexibly responsive than those now current. ${ }^{\prime 97}$ Both Dewey and Fleck hope to do this through an educative process that works to engage diverse groups of people so that 1) our own inherently limited context is broadened and 2) we can uncover the conflict in its full scope. Both believe this is only possible through an experimental process that focuses on the need for amicable cooperation. In the end, we are searching for shared ends, common values, and practical, though provisional, agreement subject to future deliberative efforts. In the end, we are working to create a public. This is precisely what we need when facing such complex and changing circumstances in the medical field.

To this end, Walter Feinberg's article, "The Idea of a Public Education," reawakens Dewey's work on the creation of publics. Feinberg defines a public as "a group of strangers tied together by consciousness of a common fate" who are also in "communication with one another about the viability of commonly held values." Such individuals will certainly have different identities and values, but will care about the interests of others and demonstrate "a willingness to seek common principles. ${ }^{\prime 98}$ Citizen participation, Feinberg argues, is essential to confronting the complex problems we face today.

Dewey, however, fails to systematically discuss "the idea of educating a

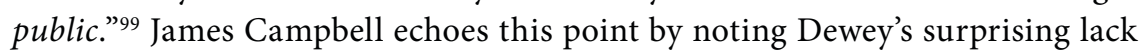
of detailed analysis on his method of social reconstruction; "Instead we get a series of hints and suggestions." ${ }^{100}$ While we never get a full accounting of his "method of social reconstruction," we can still see what is clearly involved: "The community formulates the problem, develops facts, evidence, and explanations, 


\section{Danielle L. LAKE}

reasons carefully to develop hypotheses, and evaluates these hypotheses through practical social interaction." ${ }^{.101}$ It is by engaging in this process, by identifying the problem, researching solutions, and weighing options that the public is created. ${ }^{102}$

While Feinberg notes the shortfalls of Dewey's unsystematic engagement with the issue, he still finds value in referencing Dewey to make his case. "Dewey," Feinberg says, "provides the impetus for this movement [deliberative democracy], and in doing so he begins implicitly to acknowledge the public as more than ... a community of interests or sentiments" ${ }^{\prime 103}$ On the other hand, Ralston's article, "Dewey's Theory of Moral (and Political) Deliberation Unfiltered," argues that the recent move to co-op Dewey as a proto-democratic deliberative theorist is a serious mistake. As evidence, Ralston cites the fact that Dewey never actually wrote much about "deliberation"; instead he spoke of "communication" and "dialogue". ${ }^{104}$ Ralston's point, while true, in part speaks to Dewey's failure to explain his method systematically, as noted above. Dewey's work here is vague, Ralston says, because he is concerned with "democracy as a social idea," not with the "institutional phase" as democratic deliberative theorists are today ${ }^{105}$ However, it is no real stretch to say that Fleck's work is inspired by Dewey's own. Indeed, to a great extent, Just Caring follows the method and echoes the spirit of a Deweyan ethics.

In the end, though, Fleck does not adequately deal with the trouble of accurately estimating one's future health care desires, nor with the very real power differentials we face on the ground. In truth, however, many further decisions about the implementation of such deliberative committees would need to be made. To this end, Fleck has not only studied previous deliberative efforts but also conducted such deliberations of his own. Then again, he is a little too eager to limit our deliberative efforts through his constitutional principles, but deflects such reliance via a willingness to revise such principles if they show themselves to be detrimental to the process. Finally, his dependence on John Rawls and Norman Daniels is, at times, inconsistent with a pragmatic agenda. But, as I've argued, Fleck almost always finds his way back. For a scholar of American philosophy, Fleck's Deweyan, pragmatic roots shine through.

It is my hope that Fleck's rational democratic deliberation could begin to build a foundation for further cooperation, for greater education about the various and complicated bioethical situations we must confront and, finally, for establishing working solutions that are amenable to adjustment. Through this process the isolated individual recognizes the face of others and therein recognizes their plight as worthy of his time and effort. While it moves us to act on these matters, it also moves us to be reflective about the actions we take. James Campbell sums up these two steps when he writes that while "it is necessary for us to step back to understand; it is also necessary for us to move forward to live." 106 This process of stepping back and moving forward becomes a constant dance of readjustment to changing circumstances, but it is through such a process that we are more likely to derive solutions that work for the circumstances we currently face. 


\section{REFERENCES}

Campbell, James. The Community Reconstructs. Chicago: University of Illinois, 1992. -_- Understanding John Dewey. Chicago: Open Court, 1996.

Dewey, John. "Creative Democracy: The Task Before Us." The Later Works, 19251953, (14). Ed. Jo Ann Boydston, 225-231. Carbondale: Southern Illinois University Press, 1986.

- - - "Context and Thought." The Later Works, 1925-1953, (6). Ed. Jo Ann Boydston. Carbondale: Southern Illinois University Press, 1986.

- - . Democracy and Education. The Middle Works, 1899-1924, (9). Ed. Jo Ann Boydston. Carbondale: Southern Illinois University Press, 1980.

-_- Human Nature and Conduct. The Middle Works, 1899-1924, (14). Ed. Jo

Ann Boydston. Carbondale: Southern Illinois University Press, 1983.

_-_. "Logical Method and Law." The Middle Works, 1899-1924, (15). Ed. Jo Ann

Boydston. Carbondale: Southern Illinois University Press, 1983.

- _- "The Pattern of Inquiry" in Logic: the Theory of Inquiry. The Later Works, 1925-1953, (12). Ed. Jo Ann Boydston. Carbondale: Southern Illinois University Press, 1986.

- - . The Public and Its Problems. The Later Works, 1925-1953, (2). Ed. Jo Ann Boydston. Carbondale: Southern Illinois University Press, 1984.

Feinberg, Walter. "The Idea of a Public." Review of Research in Education. 26, no. 1 (2012): 1-19.

Fleck, Leonard. Just Caring: The Ethical Challenges of Health Care Rationing and Democratic Deliberation. New York: Oxford University Press, 2009.

Gutmann, Amy and Dennis Thompson. Democracy and Disagreement. Cambridge: Harvard University Press, 1996.

Gold, Martha R., Shoshanna Sofaer and Taryn Siegelberg. "Medicare and CostEffectiveness Analysis: Time to Ask the Taxpayers." Health Affairs 26, no 5 (2007): 1399-1406.

Levine, Peter, Archon Fung, and John Gastil. "Future Direction for Public Deliberation." The Deliberative Democracy Handbook. Edited by John Gastil and Peter Levine, 271-286. San Francisco: Jossey-Bass, 2005.

Neibuhr, Reinhold. Moral Man and Immoral Society. Louisville: Westminster John Knox Press, 2001 [1933].

Pappas, Gregory. John Dewey's Ethics: Democracy as Experience. Bloomington: Indiana University Press, 2008.

Ralston, Shane. "Intelligently Designing Deliberative Health Care Forums: Dewey's Metaphysics, Cognitive Science and a Brazilian Example." The Review of Policy Research 25, no. 6 (2008): 619-630.

- - . "Dewey's Theory of Moral (and Political) Deliberation Unfiltered." Education and Culture 26, no. 1 (2010): 23-43. 


\section{DANielle L. LAKE}

Schutz, Aaron. "John Dewey and 'a Paradox of Size': Democratic Faith at the Limits of Experience." American Journal of Education 109, no.3 (2001): 287-319.

Weber, Eric Thomas. Rawls, Dewey and Constructivism: On the Epistemology of Justice. London: Continuum International Publishing, 2010.

Young, Iris Marion. Inclusion and Democracy. New York: Oxford University Press, 2000.

\section{Notes}

1. John Dewey, The Public and its Problems, ed. Jo Ann Boydston (Carbondale: Southern Illinois University Press, 1984 [1927]), LW 2, 287.

2. Fleck has also served as director of a statewide effort in Michigan in community engagement and education in order to inform policy and as a staff ethicist for the Governor's Task Force on Health Care. He has since been a co-principal investigator on a number of NIH grant projects focused on engaging the public in bioethical issues.

3. The argument that we do not need to ration such resources is quickly proved to be unsound. No matter how frugal we are and no matter how much "waste" we minimize in allocating our resources, we will never eliminate the need to ration because we are not dealing with unlimited resources.

4. Walter Feinberg, "The Idea of a Public," in Review of Research in Education 26, 1 (2012): 14-5.

5 Fleck references his project as pluralistic, non-foundational, experimental, and, finally, as rationally democratic $(2008,8)$.

6. James Campbell, The Community Reconstructs, (Chicago: University of Illinois, 1992), 8.

7. Gregory Pappas, John Dewey's Ethics, (Bloomington: Indiana University Press, 2008), 19.

8. Leonard Fleck, Just Caring: The Ethical Challenges of Health Care Rationing and Democratic Deliberation, (New York: Oxford University Press, 2009), 56 (emphasis mine).

9. Amy Gutmann and Dennis Thompson, Democracy and Disagreement, (Cambridge: Harvard University Press, 1996), 16.

10. John Dewey, Human Nature and Conduct, ed. Jo Ann Boydston (Carbondale: Southern Illinois University Press, 1983), MW 14, 52.

11. In 2002 the Institute of Medicine concluded that approximately 20,000 uninsured Americans die every year because of complications directly traceable to a lack of insurance (Fleck vii).

12. Gutmann and Thompson, Democracy and Disagreement, 26.

13. Fleck also references the need for impartiality, in contrast to the influence of interest groups, politics and power. To this extent, he is not proposing that we somehow develop a point-of-view from nowhere, but rather a point-of-view free from unfair coercion.

14. Fleck, Just Caring, 116.

15. Dewey, MW 14, 144.

16. If, on the other hand, we have the personal means to invest in our health care needs we are usually free to do so as long as it does not impinge on others' ability to gain care within the social system.

17. Fleck, Just Caring, 116.

18. Aaron Schutz, "John Dewey and a 'Paradox of Size': Democratic Faith at the Limits of Experience," in American Journal of Education 109, 3 (2001): 294. 
19. Dewey, MW 14: 116.

20. John, Dewey, “Creative Democracy - The Task Before Us," ed. Jo Ann Boydston (Carbondale: Southern Illinois University Press, 1986), LW 14: 228.

21. John Dewey, "Education and Social Direction," ed. Jo Ann Boydston (Carbondale: Southern Illinois University Press, 1982), MW 11: 57.

22. Schutz, "John Dewey and Paradox," 296.

23. Ibid.

24. Dewey, LW 2: 331.

25. Ibid., 366.

26. Reinhold Neibuhr, Moral Man and Immoral, (Louiseville: Westminster John Knox Press, 2001), 116.

27. Some pragmatists, like Jane Addams, will argue that it is not that we need to get passed our loyalties, but instead that we need to expand our loyalties.

28. Dewey, MW 14: 86.

29. John Dewey, “The Pattern of Inquiry," in Logic: The Theory of Inquiry, ed. Jo Ann Boydston (Carbondale: Southern Illinois University Press, 1986), LW 12: 109.

30. John Dewey, "Logical Method and Law," ed. Jo Ann Boydston (Carbondale: Southern Illinois University Press, 1983), MW 15: 76.

31. Just Caring is littered with numerous complex, head-scratching bioethical dilemmas that do not subject themselves to easy analysis or quick categorization. But such examples are also scattered more broadly across his published works. See, for instance, "Just Caring: Managed Care and Protease Inhibitors." In J. Arras and B. Steinbock (eds.) Ethical Issues in Modern Medicine, 5th ed. Mountainview, CA: Mayfield Publishing, 679-86 or "Last Chance Therapies: Can a Just and Caring Society do Health Care Rationing when Life Itself is at Stake" Yale Journal of Health Policy, Law, and Ethics 2 (2): 255-98.

32. Neibuhr, Moral Man and Immoral, 174.

33. John Dewey, Democracy and Education, ed. Jo Ann Boydston (Carbondale: Southern Illinois University Press, 1980), MW 9: 35-6.

34. Schutz, "John Dewey and Paradox," 290.

35. Fleck, Just Caring, 17.

36. Eric Weber, Rawls, Dewey and Constructivism: On the Epistemology of Justice, (London: Continuum International Publishing, 2010), 2.

37. Dewey, LW 2: 271.

38. Pappas, John Dewey's Ethics, 47.

39. Fleck distinguishes the Equality Principle from the Fair Equality of Opportunity Principle. While equality refers to the complex task of attempting to treat sufficiently alike cases alike, fair equality of opportunity is derived from Norman Daniels' work. This principle tells us that the health needs we should be concerned with are connected to "protecting fair and effective equality of opportunity." Opportunity is broadly construed to encompass a wide spectrum of experiences "that make life interesting and meaningful and fulfilling" for different people (191).

40. The Liberal Neutrality principle simply refers back to the necessity for justifying our decisions with public reasons. The strength and weaknesses of this approach are discussed further in the paper.

41. Fleck, Just Caring, 185.

42. Dewey, LW 12: 502.

43. Ibid., MW 9, 88-9.

Volume 29 (2) 2013 


\section{DANielle L. LAKE}

44. Weber, Rawls, Dewey and Constructivism, 133.

45. Ibid., 136.

46. Dewy, LW 2: 264.

47. Campbell, The Community Reconstructs, 42 .

48. Fleck, Just Caring, 102.

49. Dewey, LW 2: 346.

50. Fleck, Just Caring, 184.

51. Pappas, John Dewey's Ethics, 46.

52. Schutz, "John Dewey and Paradox," 306.

53. Ibid., 312 and Peter Levine, Archon Fung, and John Gastil, "Future Direction for Public Deliberation," in The Deliberative Democracy Handbook, Ed.s John Gastil and Peter Levine, (San Fransisco: Jossey-Baas, 2005), 275.

54. Fleck, Just Caring, 134.

55. Dewey, LW 2: 341.

56. Iris Marion Young, Inclusion and Democracy, (New York: Oxford University Press, 2000), 6 .

57. Ibid., 55.

58. Fleck does not offer us any definite guidelines for how to ensure our committees are sufficiently diverse or for what this might even mean. Instead, he suggests that we need to begin to think about and discuss what sufficient diversity might be. He is willing to begin this process now and risk not being sufficiently diverse as long as we revise the make-up of our committee based on what we learn through engaging in the process.

59. Dewey, LW 2: 341.

60. Ibid., MW 14: 70.

61. Fleck does not, however, offer a concrete plan for how we will engage the greater community more informally. He suggests the possible use of the internet and other various forums for a broader discussion that will then feed into the formal committees.

62. John Dewey, "Context and Thought," ed. Jo Ann Boydston (Carbondale: Southern Illinois University Press, 1986 [1938]), LW 6: 21.

63. Fleck, Just Caring, 195, 196.

64. Martha R. Gold, Shoshanna Sofaer, and Taryn Siegelberg, "Medicare and CostEffectiveness Analysis: Time to Ask the Taxpayers," in Health Affairs 26, 5 (2007): 1400-1.

65. Ibid., 1402-3.

66. Levine et al., "Future Direction for Public," 272.

67. Fleck, Just Caring, 128.

68. Ibid., 163.

69. Dewey, MW 14: 55.

70. Fleck, Just Caring, 198.

71. Ibid.

72. Ibid., 199.

73. Ibid., 9.

74. Dewey, MW 14: 138.

75. Neibuhr, Moral Man and Immoral, 27-8.

76. Fleck, Just Caring, 94.

77. Dewey, LW 2: 362.

78. Ibid., MW 14: 11.

79. Ibid., MW 9: 252. 
80. Neibuhr, Moral Man and Immoral, 196.

81. Dewey, LW 2: 366.

82. Levine et al., Deliberative Democracy Handbook, 274.

83. Dewey, MW 14: 21.

84. Ibid., LW 2: 336.

85. Ibid.

86. Ibid., MW 14: 43.

87. Schutz, "John Dewey and Paradox," 288.

88. Ibid., 289.

89. Ibid., 290.

90. Dewey, LW 2: 273.

91. Ibid., MW 14: 18.

92. Schutz, "John Dewey and Paradox," 291.

93. Feinberg, "Idea of a Public," 17.

94. By saying that these procedures are only theoretically built into Fleck's deliberative process, I only mean to highlight that this particular process has yet to be enacted or tested on any large scale. Thus, the intermediate acts laid out should occur if the deliberative process and the bureaucracy required to enact the committee's decisions proceeds as it is intended.

95. Dewey, MW 14: 38.

96. Ibid., 48.

97. Ibid., 90.

98. Feinberg, "Idea of a Public," 14.

99. Ibid., 7.

100. Campbell, The Community Reconstructs, 43.

101. Ibid., 46.

102. Dewey, LW 2: 370.

103. Feinberg, "Idea of a Public," 9.

104. Shane Ralston, “Intelligently Designing Deliberative Health Care Forums: Dewey's Metaphysics, Cognitive Science and a Brazilian Example," in The Review of Policy Research 25, 6 (2008): 30 .

105. Ibid., 32.

106. James Campbell, Understanding John Dewey, (Chicago: Open Court, 1996), xii.

Danielle L. Lake is at Grand Valley State University.

E-mail: lakeda@gvsu.edu 
